\title{
Willingness to Pay for Renewable Energy in Myanmar: Energy Source Preference
}

\author{
Masako Numata ${ }^{1, *(\mathbb{D}}$, Masahiro Sugiyama ${ }^{1} \mathbb{D}$, Wunna Swe ${ }^{2}$ and Daniel del Barrio Alvarez ${ }^{3}$ (D) \\ 1 Institute for Future Initiatives, The University of Tokyo, Tokyo 113-0033, Japan; \\ masahiro_sugiyama@alum.mit.edu \\ 2 Department of Electrical Power Engineering, Mandalay Technological University, Mandalay 05072, Myanmar; \\ wunnaswe@mtu.edu.mm \\ 3 Department of Civil Engineering, The University of Tokyo, Tokyo 113-8656, Japan; \\ danieldelbarrioalvarez@g.ecc.u-tokyo.ac.jp \\ * Correspondence: m.matsuo-numata@05.alumni.u-tokyo.ac.jp
}

Citation: Numata, M.; Sugiyama, M.; Swe, W.; del Barrio Alvarez, D. Willingness to Pay for Renewable Energy in Myanmar: Energy Source Preference. Energies 2021, 14, 1505. https://doi.org/10.3390/en14051505

Academic Editor: Meenakshi Rishi

Received: 8 February 2021

Accepted: 7 March 2021

Published: 9 March 2021

Publisher's Note: MDPI stays neutral with regard to jurisdictional claims in published maps and institutional affiliations.

Copyright: (c) 2021 by the authors. Licensee MDPI, Basel, Switzerland. This article is an open access article distributed under the terms and conditions of the Creative Commons Attribution (CC BY) license (https:// creativecommons.org/licenses/by/ $4.0 /)$.
Abstract: The increased use of renewable energy is imperative as a countermeasure to climate change. As with conventional electricity generation technologies, public acceptance of renewables is an important issue, and willingness to pay (WTP) is a widely used indicator to assess such public attitudes. Unfortunately, the literature to date mostly covers developed countries, with few WTP surveys in developing countries. Tackling climate change is an urgent issue for these developing countries; therefore, understanding of public attitudes toward renewables in developing countries is crucial. This study conducted the first survey on WTP for introducing renewable energy in Myanmar. Although Myanmar boasts abundant renewable energy resources, including solar power and biomass in addition to large-scale hydro plants, its resources are not being properly utilized to generate electricity. This study surveyed WTP for power generation by solar photovoltaics, small hydropower, and biomass facilities. The results showed the highest WTP for solar power (USD 1.92) with $10 \%$ share in the energy mix, and lower WTP for biomass and small hydropower electricity generations (USD 1.13 and USD 1.17, respectively). Careful public communication is thus crucial for expanding biomass and small-scale hydro power plants.

Keywords: willingness to pay; renewable energy; Myanmar; climate change; stated preference; discrete choice experiment (DCE); random utility theory; energy policy

\section{Introduction}

As emphasized by the widespread ratification of the Paris Agreement, it has been globally acknowledged that strategies to combat climate change are urgently required. To reduce the production of greenhouse gases, the use of renewable energy must be expanded in the energy sector. Public acceptance of attendant costs will be important for progress by strategically expanding the use of renewable energy.

One indicator of the level of public acceptance is the willingness to pay (WTP). Although many methods to measure WTP have been developed in the field of environmental economics, for example, discrete choice experiment (DCE) and contingent valuation methods [1], they are currently widely used in other fields as a means of investigating consumer preferences. Although there are a comparatively high number of previous studies on the WTP for renewable energy in economically developed countries, there are fewer studies that target less economically developed nations in Asia. The countries targeted for WTP analysis regarding the adoption of renewable energy and other climate change countermeasures are mostly economically developed. According to a meta-analysis of 11 studies, 363 such studies targeted high-income countries, 66 upper-middle-income countries, 3 lower-middle-income countries, and 1 that targeted a low-income country [2-12]. 


\subsection{Literature Review}

Very few studies on WTP for renewable energy have targeted the less developed economies in Asia; five studies on China [13-17], eight on India [18-25], three on Indonesia [26-28], three on Malaysia [29-31], and one each on Kazakhstan [32], Laos [33], Pakistan [34], the Philippines [35], Thailand [36], and Myanmar [37]. Their detailed research topics vary widely and include the research and development of solar energy [37], green electricity [14,16,30-32], improved electricity services [19,21,27], rural electrification [22,23], rural electrification with mini-grids [20,28,34,38], off-grid solar [13], electricity [18], ecotourism [33,35], electric motorcycles [17], solar home systems in grid-connected areas [36], solar lanterns [24], and climate change mitigation [26]. Furthermore, the WTP results for green electricity in these previous studies varied depending on the study and the targeted country, ranging from an average WTP per month of USD 0.82 [30] in Malaysia, from USD 1.15-1.51 [16] to USD 2.7-3.3 [14] in China, and USD 1 for the research and development of solar energy in Myanmar [37]. Contingent valuation method was applied for these studies $[14,16,30,37]$.

This study specifically investigates the WTP for renewable energy in Myanmar. The WTP for research and development into solar energy in Myanmar has already been studied; this nation benefits not only from sunshine for the generation of electricity using solar energy but also with abundant water for hydroelectricity generation. Electricity has also been generated in biomass facilities fueled by rice husks, a byproduct of rice cultivation, which is itself a major agricultural product.

\subsection{Energy Situation in Myanmar}

Hydroelectricity generation has played the largest role in the country (Figures 1 and 2) because Myanmar has four major rivers (Ayeyawady, Chindwin, Thanlwin, and Sittaung) and $7.7 \%$ of Asia's total hydroelectric generation resources [39]. The future potential capacity of large-scale hydroelectricity generation systems is $100 \mathrm{GW}$, and that of small- to medium-sized hydroelectric generation systems is $230 \mathrm{MW}$ [40]. The current composition of the sources of electricity in Myanmar relies on hydropower; within the total electricity generated, hydroelectricity generation accounts for $56 \%$, gas-fired power generation for $42 \%$, and the only coal-fired power stations for $2.3 \%$ [41]. This reliance on hydroelectric generation leads to the occurrence of outages during the dry season [42]; because the generation capability falls in this season and because the capacity factor falls, there are outages, despite the fact that the installed capacity outstrips peak demand [41]. As a result, strengthening the electricity-generating capability of the country is urgently required.

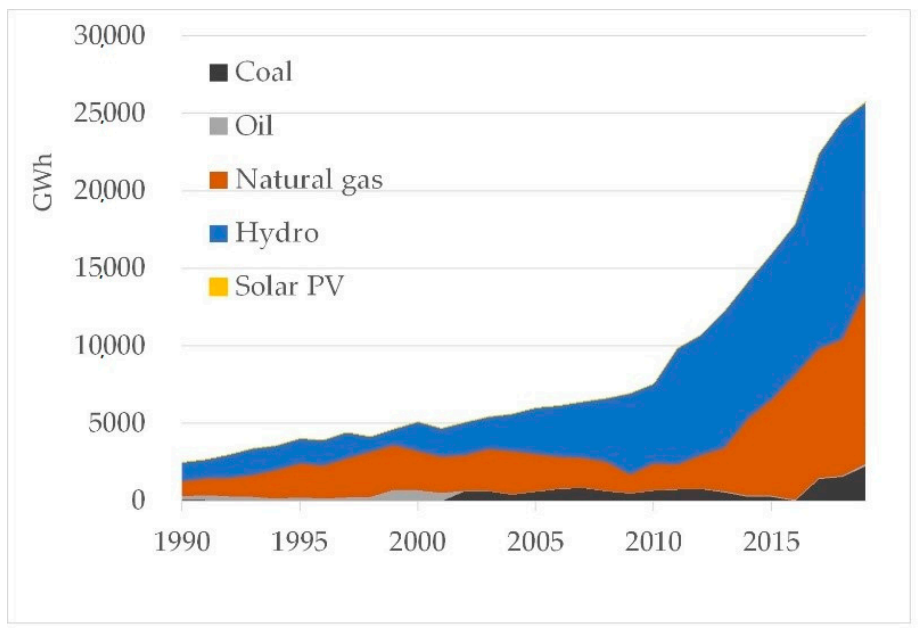

Figure 1. Electricity generation by sources. Reproduced by the authors based on the data from the International Energy Agency (IEA) [43]. 


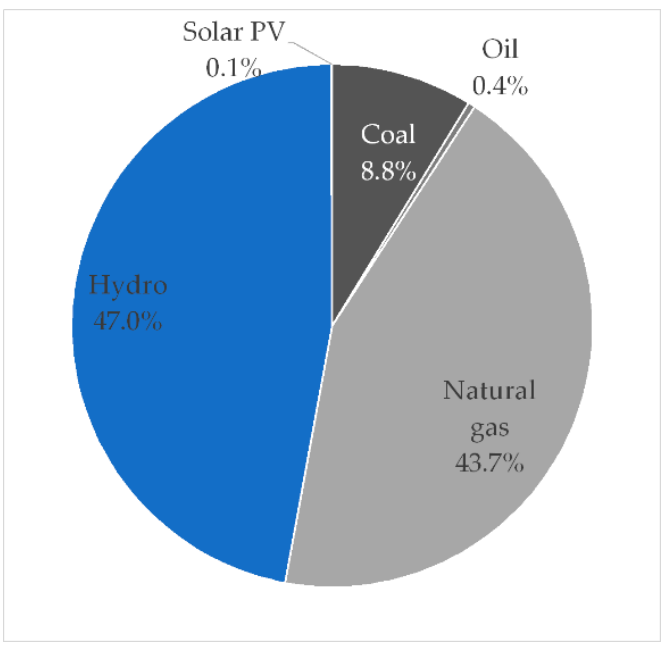

Figure 2. Current share of electricity generation by sources [43].

Therefore, the Ministry of Electricity and Energy (MOEE) plans to develop new hydroelectric generation dams. However, as emphasized by the decision to suspend the Chinese-led Myitsone Dam project under the previous Thein Sein administration, a growing opposition movement has increased the difficulties surrounding large-scale dam development [44]. Project transparency, stakeholder involvement, and proper consultation have become even more necessary, especially in the regions inhabited by ethnic minorities and those ravaged by conflict. However, given the government's limited capabilities and resources, there is doubt as to whether the handling of the matter will improve in the future [44]. Twelve of the existing 26 dams and 42 of the 50 planned dams are located in areas of conflict or inhabited by ethnic minorities [45]. Considerable efforts are thus needed for dam development to proceed as planned. Additionally, the MOEE has announced its plans for four large-scale gas-fired power stations, but their completion within deadlines is also open to question [41]. With no large-scale power stations in the pipeline whose construction is straightforward, it is necessary to consider whether strengthening the electricity generating capability of the country will progress as planned.

Furthermore, the proper utilization of renewable energy resources other than hydropower has not been investigated. The peak technical potential for solar power generation is $27 \mathrm{GW}$ [46] and the biomass electricity generation capacity potential is $12 \mathrm{GW}$ [47]. However, under the power resource balance scenario of the National Electricity Master Plan, the share of renewable energy excluding large-scale hydropower systems is set exogenously at only $9 \%$ of the 2030 installed capacity. The National Electricity Master Plan was proposed in 2015 with the support of the Japan International Cooperation Agency (JICA) [48], whose scenario selected 2019 to realize universal access to electricity [49]. Myanmar ratified the Paris Agreement [50] and stated that, within its Nationally Determined Contributions, it would implement mitigating actions in line with the demands for sustainable development [51]. As a result, a further evaluation of the nation's existing renewable energy resources is required.

In this study, the WTP was investigated using a discrete choice experiment targeting households in Mandalay, Myanmar's second city. Mandalay is located near the middle of Myanmar, in the central dry zone, and is the nation's second-largest city after Yangon. Yangon is noticeably more developed than other parts of Myanmar in terms of education, health, and standards of living [47], while the Mandalay region ranks eighth [52] in terms of annual GDP per capita among the nation's 14 states/region and one union territory; thus, we considered it a suitable region for this study. According to the Burmese government, the proportion of households connected to the national grid was over 50\% in 2019 [53]. In this study, the WTP per household for the adoption of electricity generated using renewable energy in Myanmar was identified using a discrete choice experiment (DCE) targeting only households on the national grid. 


\section{Methodology}

\subsection{Theoretical Background}

Methods for evaluating WTP can be broadly classified as either "stated preference" $(\mathrm{SP})$ ", which evaluates the value of the environment based on people's opinions, or "revealed preference $(\mathrm{RP})$ ", which evaluates the value of the environment based on people's behavior [54]. RP includes the replacement cost method, hedonic method, and travel cost method. The replacement cost method evaluates the value of the environment based on the cost of artificially supplied goods and services similar to those provided by the environment; the hedonic method evaluates the value of the environment based on the effect of environmental quality on housing prices; and the travel cost method evaluates the value of recreation based on the cost of travel to recreation sites. In contrast, SP includes the contingent valuation method and the discrete choice experiment (DCE). The contingent valuation method is a method of directly inquiring about the value of the environment using a questionnaire survey. On the contrary, the DCE method, which is also based on questionnaires, evaluates the value of the environment by asking the preference for various alternatives to improve the environment. $\mathrm{RP}$ is based on actual behavior, and it cannot evaluate hypothetical situations. SP, by contrast, is based on the opinions expressed by people, and thus can evaluate hypothetical situations. However, because SP is based on questionnaires, the amount of valuation can be easily affected by the way of explanation; thus, it is necessary to design the survey carefully [1].

In this study, the DCE method, which is classified as SP, was used because the hypothetical situation about renewable energy was asked. Respondents were asked which of several alternatives (three alternatives in each choice set, as shown in Table 1) they preferred. It is characteristic for the DCE that the value of individual attributes that comprise each alternative is assessed.

Table 1. Sample discrete choice experiment (DCE) survey question.

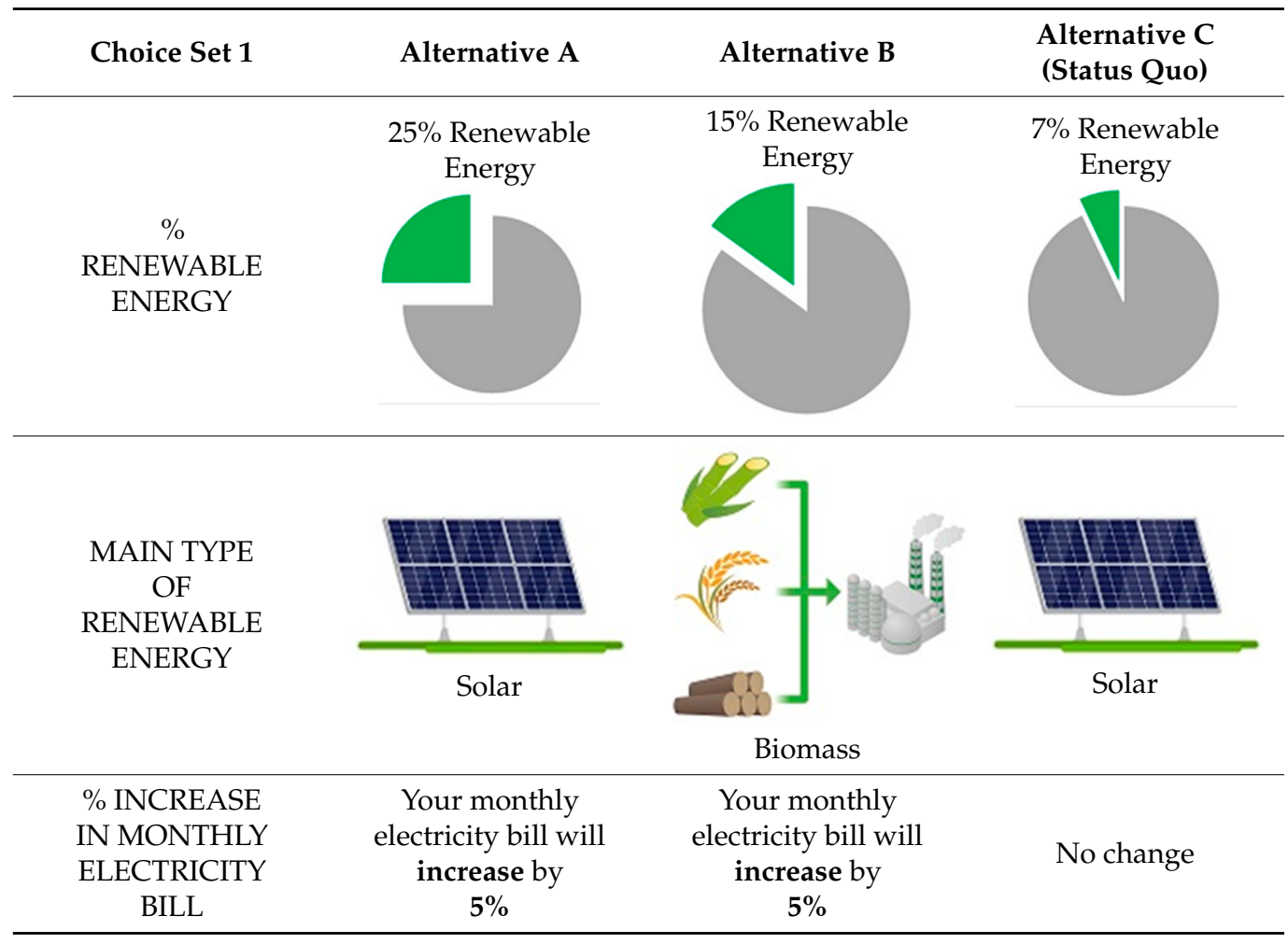

\subsection{Model for WTP Estimation}

The DCE method is based on McFadden's random utility model [55] and assumes that when respondents are presented with choice sets composed of several alternatives, they 
will always select the alternative with the greatest utility. The utility function, $U_{i j}$, when respondent $i$ chooses alternative $j$ is shown in the formula below, by combining observable systematic component $V_{i j}$ and random component $\varepsilon_{i j}$.

$$
U_{i j}=V_{i j}+\varepsilon_{i j} .
$$

Furthermore, the probability of respondent $i$ selecting alternative $j$ is expressed by the following equation [1]:

$$
\pi_{i j}=\frac{\exp \left(V_{i j}\right)}{\sum_{k} \exp \left(V_{i k}\right)} .
$$

\subsubsection{Conditional Logit Model}

McFadden's conditional logit model [55] focuses more on the characteristics of the alternative than on the attributes of the individuals, and models systematic component $V_{i j}$. $X_{j}$ expresses the vector of the characteristics of alternative, $j$, as follows:

$$
V_{\mathrm{ij}}=\beta \cdot X_{j} .
$$

$\beta$ is the vector of assumed coefficients, each of which signifies the change in utility for one unit of change in each attribute.

\subsubsection{Multinomial Logit Model}

The multinomial logit model is suitable for modeling the act of selection. It allows the characteristics (e.g., income) of the individuals involved and not just the attributes of the choice alternatives (e.g., cost) to be included as explanatory variables.

In the ordinary multinomial logit model, systematic component $V_{i j}$ is simulated from the characteristics of individual people, as shown below [56].

$$
V_{\mathrm{ij}}=\gamma_{j} \cdot Z_{i}
$$

where regression coefficient $\gamma_{j}$ expresses the change in utility when there is a one-unit change in the characteristics of an individual person.

\subsubsection{Multinomial and Conditional Logits}

Generally, in the analysis, a model that combines multinomial and conditional logits is used. Systematic component $V_{i j}$ relies on variables (e.g., the individuals' perception of the values of options) defined in relation to the characteristics of the individuals, the attributes of the option, or the individual and options combined. The typical model is usually expressed as follows [56]:

$$
U_{\mathrm{ij}}=\alpha_{\mathrm{j}}+\boldsymbol{\beta} \cdot \boldsymbol{X}_{i j}+\gamma_{j} \cdot Z_{i}+\varepsilon_{\mathrm{ij}}
$$

where $\alpha_{j}$ is an alternative specific constant, $X_{i j}$ expresses the characteristic that changes between options (whether it changes depending on the individual person), and $Z_{i}$ is the characteristic of the individual person that is constant between choice tasks.

\subsubsection{Marginal WTP}

Here, the systematic component of the utility function is expressed by the following equation:

$$
V=\sum_{n} \beta_{n} X_{n}+\beta_{\text {Price }} X_{\text {Price }}
$$

where $\beta$ is the parameter estimated by multinomial logit and, in particular, $\beta_{\text {Price }} X_{\text {Price }}$ expresses the price attribute and its parameter. The total differentiation of Equation (6) gives:

$$
d V=\sum_{n} \frac{\partial V}{\partial X_{n}} d X_{n}+\frac{\partial V}{\partial X_{\text {Price }}} d X_{\text {Price }}
$$


where the utility level is fixed $(d V=0)$ at the initial level, and attributes other than a specific attribute $k$ are assumed to be fixed $\left(d X_{n}=0, n \neq k\right)$ at the initial level. In this case, Equation (7) becomes:

$$
0=\beta_{k} d X_{k}+\beta_{\text {Price }} d X_{\text {Price, }}
$$

The marginal WTP (MWTP) when $X_{k}$, which expresses attribute $k$, then increases one unit [57]:

$$
\operatorname{MWTP}_{k}=\frac{d X_{\text {Price }}}{d X_{k}}=-\frac{\beta_{k}}{\beta_{\text {Price }}} .
$$

For this analysis, the Apollo package [58] for $\mathrm{R}$ was used. The Apollo package was developed for the estimation and application of choice models. Apollo covers the simplest Multinomial Logit model as well as a complex structure using random coefficients.

\subsection{Survey Design}

\subsubsection{Attributes and Levels}

In such surveys, the elements comprising the alternatives presented to respondents are the "attributes" and, in this paper, three attributes were set based on the discussion with experts based on previous analysis and the conditions in Myanmar: share of renewable energy within all electric power sources in 2030; type of renewable energy; and rate of increase in electricity charges. Respondents are shown a choice set, as in Table 1, and indicate their preferred option.

For the ease of respondents' understanding, the increase in the share of renewable energy within all electric power sources was assumed to have been achieved by a single type of energy, shown in the choice set. The appropriateness of each attribute level was confirmed by conducting a pretest with a sample size of 30 . Table 2 lists the attributes and their respective levels. Levels were set based on the results of the pre-tests before the main survey.

Table 2. Attributes and their levels for the survey.

\begin{tabular}{ccc}
\hline Share of RE in 2030 & Type of RE & $\begin{array}{c}\text { Increase in Monthly } \\
\text { Electricity Tariff }\end{array}$ \\
\hline $10 \% / 15 \% / 25 \% / 35 \%$ & Solar/biomass/small-scale hydro & $2 \% / 5 \% / 10 \% / 15 \% / 25 \%$ \\
\hline
\end{tabular}

The current share of renewable energy in Myanmar, excluding large-scale hydroelectric generation, was 0\% [43]. According to the Myanmar government, the energy mix in 2030 will be based on the power resource balance scenario [48] created with the support of JICA [49]. This scenario puts the share of renewable energy, excluding large-scale hydroelectric generation, in 2030 at $15 \%$, of which $6 \%$ would be from small- to medium-sized hydropower systems, and 9\% from unspecific renewal energy sources [48]. In 2018, the MOEE announced renewable energy adoption targets of $8 \%$ by 2021 and $12 \%$ by 2025 [59]. In view of the current global increase in demands for aggressive strategies to counter climate change, however, the government's targets for the adoption of renewable energy cannot be deemed adequate, and they need to be raised. Therefore, in our survey, we set the relevant levels higher.

\subsubsection{Blocks and Choice Sets}

Using Matlab's cordexch function, a D-optimal design was generated, comprising 86 choice sets formed from three alternatives; two hypothetical and one describing the current situation. The number of responses per respondent was around 5-10 [1], being set at 7-8 for the purpose of this study. Each group, comprising 7-8 choice sets apportioned to each respondent, is known as a "block". The blocks were allocated to respondents in so that a similar number answered each block. 


\subsubsection{Sampling Strategy}

The sample size required for calculating WTP using a DCE differs from study to study. According to Kuriyama et al. (2013) [1], statistical analysis is possible for a sample size of 200. In this paper, we followed de Bekker-Grob, Donkers, Jonker, and Stolk [60] to calculate the sample size, using Equation (10):

$$
\frac{n t a}{c}>500
$$

where $n$ is the number of respondents, $t$ is the number of tasks, $a$ is the number of alternatives, and $c$ is the largest number of attribute levels.

For our design, $c=5, t=7$ as the minimum, and $a=2$, because the "status quo" alternative should not be counted. Therefore, the number of respondents was $n>178.6$. We collected 250 responses to our survey. After excluding two responses that did not meet the respondent conditions, 248 responses were analyzed.

The area targeted for the survey covered five townships, namely, Aungmyaytharsan, Chanayetharsan, Maharaungmyay, Chanmyatharsi, and Pyigyeetagone, shown in the bottom-right corner of Figure 3. We chose five of the seven townships in Mandalay City, which are centrally located. The electricity provider for this area is the Mandalay Electricity Supply Corporation, which supplies 244,814 households in the area (as of November 2019). The 250 respondents were selected via random spatial sampling within the survey area, with the random extraction of coordinates.

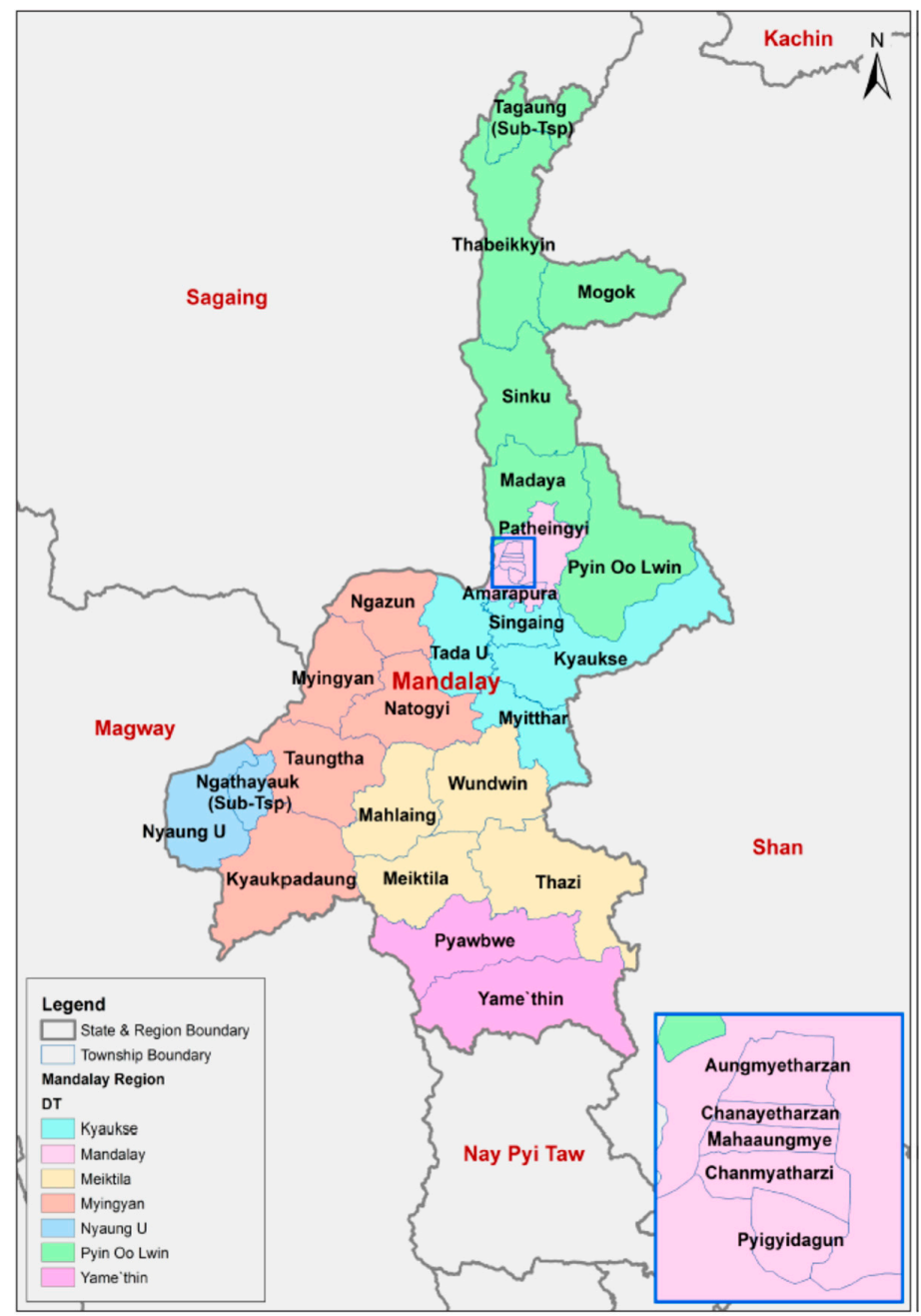

Figure 3. Map of Mandalay region [61]. 
The multinomial logit model allows the inclusion of the selection behavior characteristics of individuals as explanatory variables, as well as the attributes included in the alternatives. We considered characteristics such as gender, income, and education, as utility functions, and proposed and tested the following hypotheses: (1) the higher the respondent's education level (years of schooling), the higher the WTP; (2) the higher the respondent's income is, the higher the WTP; (3) a respondent with children will show a high WTP; (4) a respondent with strong concerns about electricity shortage will show a low WTP; and (5) a respondent with strong concern about climate change will show a high WTP.

\subsubsection{Structure of the Questionnaire}

The questionnaire began with explaining the purpose of the survey. The first part discussed electricity consumption, and respondents were reminded about their households' consumption. The second part asked about the electricity usage, for example, their appliances. The third part was the core of the survey-seven to eight choice experiment questions and follow-up questions. The fourth part covered their attitudes toward environmental issues. The fifth part asked socio-demographic information of respondents.

\section{Results}

\subsection{Descriptive Statistics}

Face-to-face surveys were conducted in July and August 2020. The state of emergency period because of the COVID-19 pandemic meant that the surveys were conducted later than planned, but the intended sample size was achieved. The survey was administered by students from Mandalay Technological University after training. Table 3 shows the respondents' socio-demographics. The respondents were predominantly female, probably because the surveys were conducted during the day (surveys were not conducted at night mainly due to consideration for the safety of the researchers). The average age of the respondents was 45.2 and the average length of their education was 11.7 years (median = 10 years). The Myanmar education system comprises four years of primary school, four years of middle school, and two years of high school; then, depending on the subjects studied, 2-3 years of college or 4-7 years of university, with two years for a master's degree. Therefore, 10 years of education are equivalent to high school graduation. The median monthly income of those responding was MMK 500,000, or USD 345. The average number of people per household was 5.4, including an average of 0.4 children under six and 0.7 elderly people.

Figure 4 shows the answers to a question regarding whether respondents considered the different sources of renewable energy to be environmentally friendly or not. The majority of respondents considered solar energy to be environmentally friendly, with a total of $91 \%$ of respondents selecting either: "1. Very Environmentally Friendly" or " 2 . Environmentally Friendly". The results were similar for small-scale hydropower, with the same combined percentage of $72 \%$. However, the same combined percentage fell to $50 \%$ for biomass, with a total of $19 \%$ of respondents selecting " 4 . Environmentally unfriendly", or "5. Very environmentally unfriendly". Moreover, with a high $31 \%$ of respondents selecting "3. Not sure" (against 8\% for solar power and 16\% for small-scale hydropower), the knowledge level regarding biomass electricity generation is relatively low. This result was consistent with the answers if respondents knew about each renewable energy source shown at the bottom of Table 3 . A total of $21 \%$ of respondents answered that they did not know about biomass, higher than 15\% for small-scale hydropower and 3\% for solar power. These results were considered reasonable. 
Table 3. Socio-demographics of respondents.

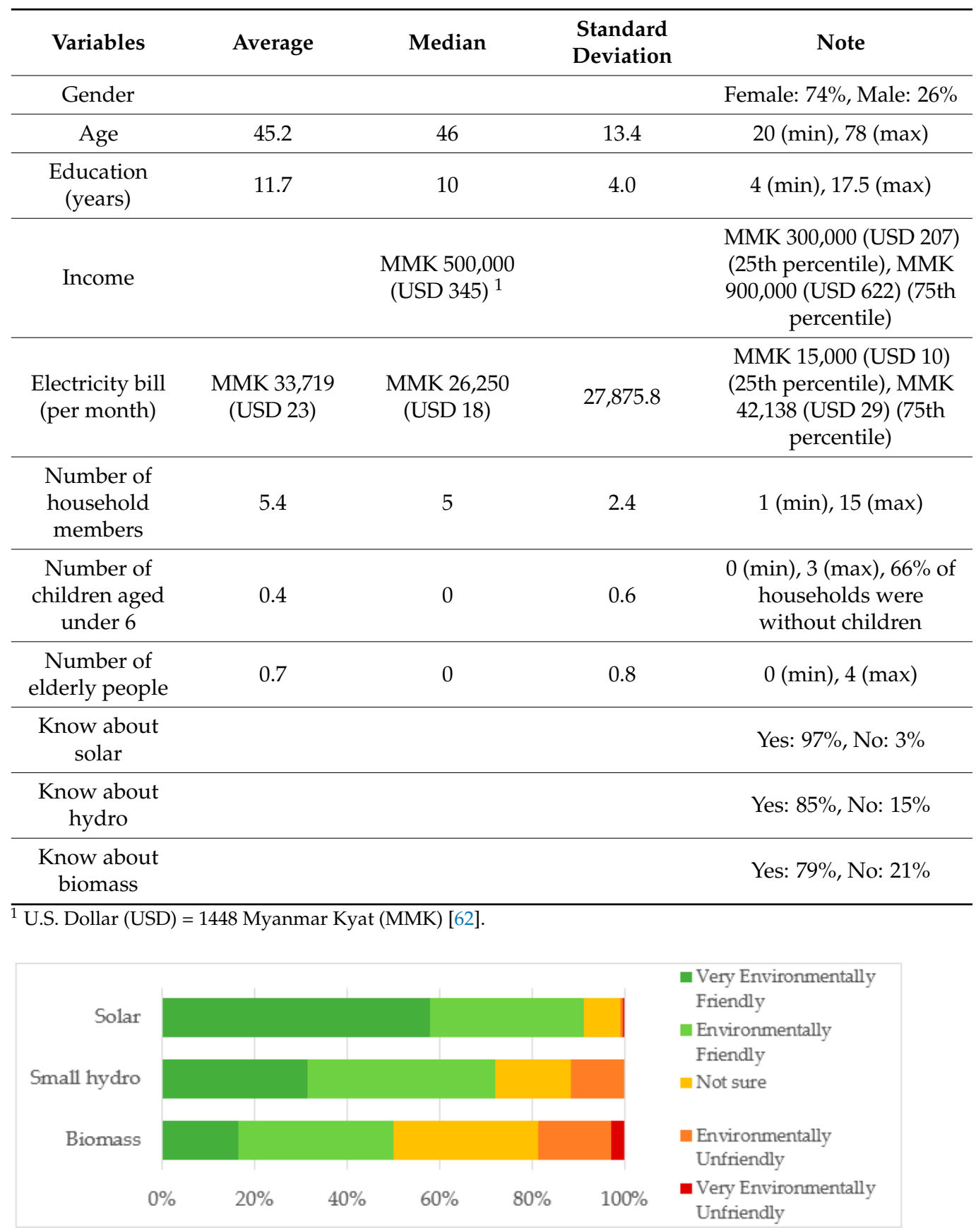

Figure 4. Opinions about the environmental friendliness of renewable energy (RE) sources.

\subsection{Estimation Results}

Table 4 reports the results for the two econometric models. Model 1 is a conditional logit model, in which only the attributes of the alternatives are independent variables, and Model 2 is a multinomial logit model, in which the characteristics of individuals are also variables. To evaluate the impact of the status quo, alternative specific constants (ASCs) are included. A positive ASC coefficient indicates that the respondent prefers an increase in the share of renewable energy from its current level. All coefficients in Model 1 have a significance level of $0.1 \%$, indicating statistical significance. 
Table 4. Estimation results.

\begin{tabular}{|c|c|c|c|c|c|c|}
\hline \multirow[b]{2}{*}{ Variables } & \multicolumn{3}{|c|}{ Model 1} & \multicolumn{3}{|c|}{ Model 2} \\
\hline & Coeff. & $\begin{array}{l}\text { Standard } \\
\text { Error }\end{array}$ & $t$ Ratio & Coeff. & $\begin{array}{l}\text { Standard } \\
\text { Error }\end{array}$ & $t$ Ratio \\
\hline ASC & $0.769 * * * 1$ & 0.116 & 6.61 & 0.747 & 0.613 & 1.22 \\
\hline Type hydro & $-0.452^{* * *}$ & 0.0874 & -5.18 & $-0.465^{* * *}$ & 0.0885 & -5.25 \\
\hline Type biomass & $-0.442^{* * *}$ & 0.0896 & -4.93 & $-0.442^{* * *}$ & 0.0909 & -4.87 \\
\hline Share & $0.0364^{* * *}$ & 0.00397 & 9.18 & $0.0378^{* * *}$ & 0.00404 & 9.35 \\
\hline Price & $-0.134^{* * *}$ & 0.00628 & -21.3 & $-0.135^{* * *}$ & 0.00638 & -21.2 \\
\hline Income $^{2}$ & & & & $-0.135()$. & 0.0995 & -1.36 \\
\hline Education & - & & & $0.0574^{* * *}$ & 0.0141 & 4.08 \\
\hline Child & & & & $0.226()$. & 0.0879 & 2.57 \\
\hline Bill & & & & $4.41 \times 10^{-6 *}$ & $2.17 \times 10^{-6}$ & 2.03 \\
\hline $\begin{array}{c}\text { Importance of } \\
\text { electricity } \\
\text { shortage }\end{array}$ & & & & $-0.228 *$ & 0.118 & -1.93 \\
\hline $\begin{array}{l}\text { Importance of } \\
\text { climate change }\end{array}$ & & & & $0.157()$. & 0.111 & 1.41 \\
\hline Log likelihood & -1778.3 & & & -1719.7 & & \\
\hline $\begin{array}{l}\text { McFadden's } \\
\text { pseudo-R } \\
\text { squared }\end{array}$ & 0.167 & & & 0.178 & & \\
\hline AIC & 3566.6 & & & 3461.3 & & \\
\hline Observations & 1944 & & & 1904 & & \\
\hline
\end{tabular}

Regarding the attributes, the share coefficient is positive, indicating that the WTP increases as the share of renewable energy increases. Because the price coefficient is negative, respondents do not prefer an increase in electricity charges. These results are intuitive. Moreover, regarding the results by the type of renewable energy with solar power as the status quo, a gap can be seen between the WTP for small-scale hydropower and biomass, and the WTP for solar power. The fact that the coefficients for both hydropower and biomass are negative shows that respondents prefer solar power and have a higher inclination to pay for it. This corresponds with the results of previous research [63] and also with Figure 4, in that the highest number of respondents were of the opinion that solar power is an environmentally friendly source of renewable energy. Therefore, the signs of the Model 1 coefficients were correct.

The analysis of Model 2 also included respondents' socio-demographic characteristics (income, length of education, whether they have children, and the environmental problems that they consider important). The Akaike information criterion (AIC) of Model 1 was 3566.64, and that of Model 2 was 3462.62. Therefore, Model 2 had a better AIC value. The respondent characteristic with the highest statistical significance for Model 2 was the length of education. As outlined previously [64], cases have been reported where respondents education has both a positive impact on their WTP [65] and a negative one [66], with the length of education also having no significant impact in some cases [67]. In this study, the impact was positive; in other words, the higher the education level, the higher the WTP for the adoption of renewable energy. This confirms Hypothesis 1.

In addition, whether a respondent has children was shown to have a significant impact on the WTP, thus confirming Hypothesis 3. This corresponds with the results in earlier research [68], because future concerns about the environment because of climate change are 
stronger in households with a child and the value of the future environment is evaluated to be higher, which seem to lead to a higher current WTP.

The income in Model 2 is the monthly household income. Hypothesis 2 is based on examples in previous studies $[37,64,68]$; however, in the results of our survey, the income coefficient was negative, showing that the higher the income, the lower the WTP. Moreover, in this study, the size of the monthly charge for electricity was shown to have a significant impact on WTP, a result that differs from earlier research [68].

We also investigated whether respondents' interest in climate change had a significant impact on the relevant WTP. Respondents were asked to indicate, from among several energy-related and environmental problems, two that they considered important. In addition to climate change, the listed problems included a shortage of electricity, a problem directly related to the electric power field, and one that consumers in Myanmar routinely face. This item was added after the DCE questions to avoid influencing the DCE results. Among the 10 options, "global warming and climate change" scored highest in terms of importance (those saying it was the most and the second most important problem were combined). "Shortage of electricity" was the third. The results are shown in Figure 5. The consistency of answers was checked using the other related question, and the inconsistent answers were excluded from the calculation of Model 2. It was clear that interest in climate change is very high in Myanmar. Additionally, from Model 2, the fact that WTP increased in line with the level of interest in climate change is shown by the relevant coefficient being positive, thus confirming Hypothesis 5. By contrast, the fact that WTP falls when the interest in shortage of electricity rises is shown by the negative relevant coefficient. This confirms Hypothesis 4. In our opinion, this is because Myanmar, where large-scale hydropower is currently the main electricity source, has frequent outages; therefore, the volatility of renewable energy is linked to the idea of electricity shortages.

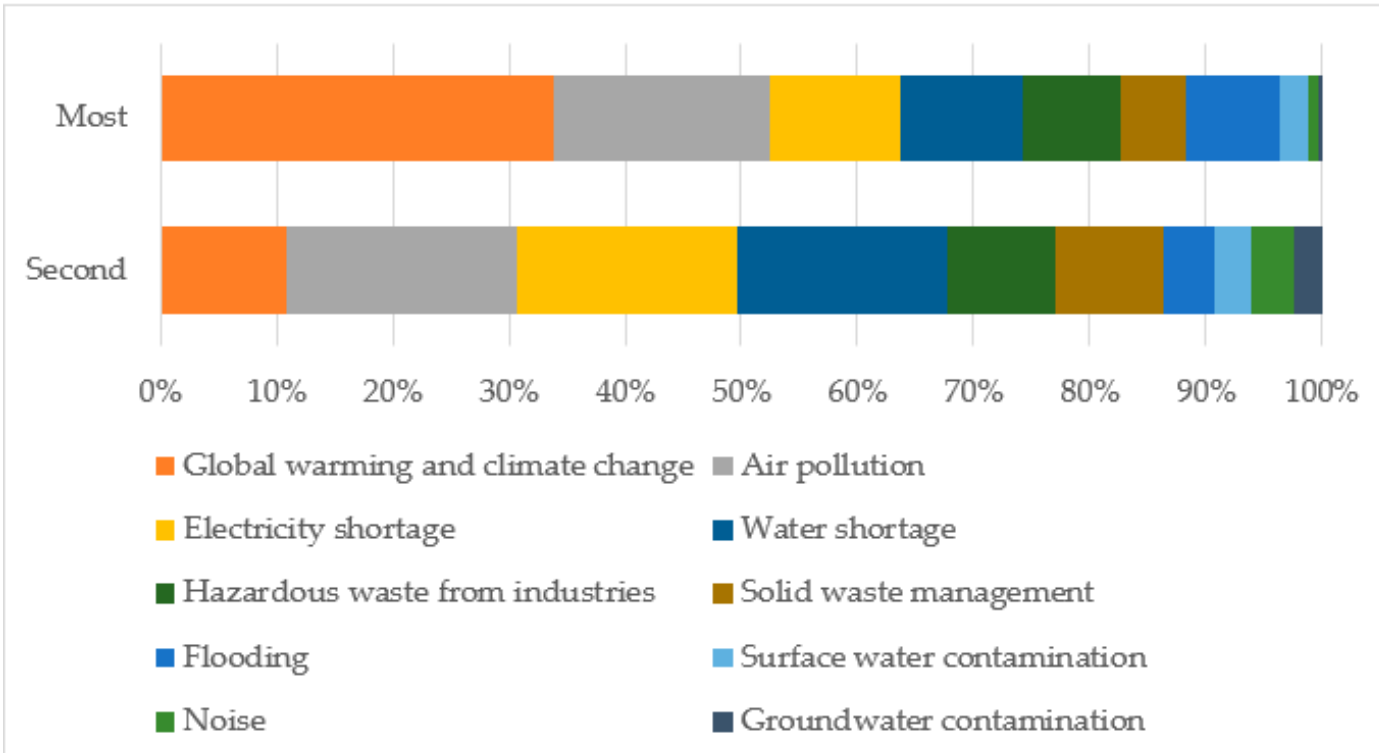

Figure 5. Energy/environmental problems considered to be of most or second most importance.

Table 5 shows the marginal WTP calculations based on each model. Standard errors were calculated using the delta method. Because respondents were asked about their WTP in terms of the percentage increase in monthly electricity charges, the monetary sums calculated based on average monthly charge are shown. Models 1 and 2 revealed that, when the share of renewable energy within electric power generation increased by $1 \mathrm{pp}$, respondents were willing to pay $0.272 \%$ (USD 0.063 ) and $0.280 \%$ (USD 0.065 ) more, respectively. Additionally, the WTP values for small-scale hydropower and biomass were $-3.44 \%$ (USD 0.79) and $-3.28 \%$, (USD 0.76) lower, respectively, thus being lower than that 
for solar power based on Model 2. According to Model 1, the values were $-3.38 \%$ (USD 0.79 ) and $-3.30 \%$ (USD 0.77) lower, respectively.

Table 5. Marginal willingness to pay (WTP) for renewable energy.

\begin{tabular}{ccccc}
\hline Marginal WTP & \multicolumn{3}{c}{ Increase in Monthly Electricity Tariff } \\
\hline & \multicolumn{3}{c}{ Model 1 } & $\mathbf{c}$ Model 2 \\
\hline & $(\%)$ & (USD) & (USD) \\
\hline Type Hydro & $-3.38 \%(0.838)$ & USD -0.79 & $-3.44 \%(0.844)$ & USD -0.79 \\
\hline Type Biomass & $-3.30 \%(0.890)$ & USD -0.77 & $-3.28 \%(0.899)$ & USD -0.76 \\
\hline Share & $0.272 \%(0.0347)$ & USD 0.063 & $0.280 \%(0.0355)$ & USD 0.065 \\
\hline
\end{tabular}

The standard error between parentheses have been calculated using the delta method.

Table 6 shows the WTP by source and share for each model.

Table 6. WTP by source and share.

\begin{tabular}{|c|c|c|c|c|}
\hline & \multicolumn{4}{|c|}{ Increase in Monthly Electricity Tariff } \\
\hline & \multicolumn{4}{|c|}{ For $10 \%$ increase in share } \\
\hline \multirow[t]{2}{*}{ Power source } & \multicolumn{2}{|c|}{ Model 1} & \multicolumn{2}{|c|}{ Model $2^{1}$} \\
\hline & $\%$ & USD & $\%$ & USD \\
\hline Solar & 8.46 & 1.97 & 8.34 & 1.92 \\
\hline Small hydro & 5.08 & 1.18 & 4.89 & 1.13 \\
\hline \multirow[t]{3}{*}{ Biomass } & 5.16 & 1.20 & 5.06 & 1.17 \\
\hline & \multicolumn{4}{|c|}{ For $25 \%$ increase in share } \\
\hline & $\%$ & USD & $\%$ & USD \\
\hline Solar & 12.49 & 2.90 & 12.54 & 2.89 \\
\hline Small hydro & 9.12 & 2.12 & 9.10 & 2.10 \\
\hline \multirow[t]{3}{*}{ Biomass } & 9.19 & 2.14 & 9.26 & 2.14 \\
\hline & \multicolumn{4}{|c|}{ For $35 \%$ increase in share } \\
\hline & $\%$ & USD & $\%$ & USD \\
\hline Solar & 15.21 & 3.54 & 15.34 & 3.54 \\
\hline Small hydro & 11.83 & 2.76 & 11.90 & 2.75 \\
\hline Biomass & 11.91 & 2.77 & 12.07 & 2.78 \\
\hline
\end{tabular}

${ }^{1}$ Coefficients not included in Equation (11) have been dropped.

Here, the WTP is calculated as Equation (11):

$$
\begin{gathered}
\text { WTP }=-\frac{\alpha+\beta_{\text {share }} \text { Share }+\beta_{\text {type }}}{\beta_{\text {Price }}} . \\
\beta_{\text {type }}=\beta_{\text {typeHydro }} \text { if type }=\text { Hydro } \\
\beta_{\text {type }}=\beta_{\text {typeBiomass }} \text { if type }=\text { Biomass }
\end{gathered}
$$

Respondents showed a willingness to pay USD 1.92 per month for a $10 \%$ increase in solar power, and USD 1.13 and USD 1.17 for small-scale hydro and biomass power, respectively, based on Model 2. According to Model 1, the values were USD 1.97, USD 1.18 , and USD 1.20 per month, respectively. Although the difference between small-scale hydropower and biomass power was small, respondents showed an overwhelmingly high WTP for solar power. 


\section{Conclusions}

We have calculated the WTP for renewable energy of the people in Myanmar for each type of renewable electric power generation source.

There has been global progress regarding the adoption of solar power, in line with the contemporary reduction in prices. Myanmar has a complementary relationship with hydroelectric power generation, which is a power source with strong seasonal fluctuations. Additionally, given people's preference for solar power in our results, this source should probably be introduced more aggressively.

Compared to solar power, the WTP was much lower for biomass. Considering that biomass was considered by $19 \%$ of the respondents as being not environmentally friendly, which is higher than the results for solar and small-scale hydro, although biomass is renewable, there is a strong concern in Myanmar regarding its impact on the environment. The emittance of tar from electricity generation using rice husks as fuel has been recognized as an issue. It is clear that people's impression of biomass has yet to improve. This is also shown by the fact that the results on WTP cast doubt on whether people consider biomass electricity generation to be environmentally friendly. However, the potential capacity of biomass electricity generation in Myanmar is high. Additionally, biomass lacks the volatility of solar power, and the output of biomass electricity generation plants can be controlled. Although it would make sense to make better use of this resource, when biomass electricity generation is introduced, careful public communication is important, such as adequate prior consultation with the relevant local communities, as well as initiatives to prevent environmental pollution, such as making it obligatory to fit equipment that stops tar emissions.

\section{Policy Implications}

The results showed a lower WTP for small-scale hydropower than for solar power. Although not as extreme as biomass, the trends were similar. Fewer respondents knew about small-scale hydropower than solar, and more respondents considered it as more environmentally unfriendly than solar. There is room for improvement in people's perceptions of small-scale hydropower. Careful public communication is thus crucial.

Although Myanmar has abundant renewable energy resources, only large-scale hydropower stations are being utilized as major electricity sources. The development of large-scale solar power stations is also in its early stages, with reports of tendering [69]; however, the National Electricity Master Plan does not contain separate targets for the adoption of renewable sources other than hydropower [70]. We believe that the first task would be to propose plans for the introduction of each type of electric power generation.

In Myanmar, stand-alone mini-grids powered by small-scale hydroelectric systems have been located in rural areas since the time of the military regime before democratization in 2011 [71]. However, some difficulties in their operation and maintenance have been pointed out, such as the distance of the site of the small-scale hydroelectric dam from the village where the energy is consumed [72]. With regard to the development of large-scale hydropower dams, their large size makes for a complex situation, giving rise to various problems and prolonging development time. Considering that several difficult cases remain unresolved, not least the Myitsone Dam, it is difficult to envisage further development of large-scale hydropower dams. It is thus necessary to focus more on small-to medium-sized hydropower dams with fewer issues and re-evaluate their roles.

In Myanmar, $70 \%$ of the population lives in rural areas [73] as does $87 \%$ of the poorest segment of the population [52]. As such, there are significant differences between urban and regional areas. In this study, we focused on urban areas when surveying the WTP in the form of additional electricity expenditure. However, to investigate the attitudes of households throughout Myanmar, further surveys in rural areas are needed. Such surveys would surely require a great deal of time and money, including the cost of securing researchers, transporting them to the relevant locations, and their accommodation. Furthermore, for the inhabitants of areas that are not on the national grid, the status quo is 
to pay no electricity charges at all. Therefore, the creation of predicated scenarios would require imagination, making it necessary to find a way to compare the relevant data with those from urban areas. Even if these conditions are difficult to meet, this would be an extremely interesting research project. Moreover, while this study analyzed survey data from Myanmar, a comparison with the WTPs for renewable energy in other countries would have great academic and practical significance, especially for developing countries where fewer studies have been carried out to date.

Author Contributions: Conceptualization, M.S. and M.N.; methodology, M.S., D.d.B.A., M.N. and W.S.; validation, M.S.; formal analysis, M.N.; investigation, W.S. and M.N.; writing—original draft preparation, M.N.; writing—review and editing, M.S.; visualization, M.N.; supervision, M.S.; project administration, M.S. All authors have read and agreed to the published version of the manuscript.

Funding: This research was funded by the Economic Research Institute for ASEAN and East Asia (ERIA).

Institutional Review Board Statement: Formal ethical review and approval were waived for this study, because it is not a medical study, does not require safety considerations for participants, or no risk of disadvantage to the vulnerable populations.

Informed Consent Statement: Informed consent was obtained from all subjects involved in the study.

Data Availability Statement: The data presented in this study are available on request from the corresponding author. The data are not publicly available due to the privacy of respondents.

Acknowledgments: This paper makes use of survey data contained in Public Attitudes toward Energy Policy and Sustainable Development in ASEAN (Yoshikawa, ed., forthcoming), published by the Economic Research Institute for ASEAN and East Asia (ERIA). However, because unsuitable data were excluded from our analysis, our results differ significantly from those reported in that publication. We would like to express our gratitude to Hisashi Yoshikawa and Wang Nan of the University of Tokyo and Truong Dang Thuy of University of Economics, Ho Chi Minh City for their great support.

Conflicts of Interest: The authors declare no conflict of interest.

\section{References}

1. Kuriyama, K.; Tsuge, T.; Shoko, Y. Shoshinnsya no Tameno Kannkyouhyouka Nyuumon; Keiso shobo: Tokyo, Japan, 2013; ISBN 9784326503728. (In Japanese)

2. Menegaki, A. Valuation for renewable energy: A comparative review. Renew. Sustain. Energy Rev. 2008, 12, 2422-2437. [CrossRef]

3. Sundt, S.; Rehdanz, K. Consumers' willingness to pay for green electricity: A meta-analysis of the literature. Energy Econ. 2015, 51, 1-8. [CrossRef]

4. Soon, J.-J.; Ahmad, S.-A. Willingly or grudgingly? A meta-analysis on the willingness-to-pay for renewable energy use. Renew. Sustain. Energy Rev. 2015, 44, 877-887. [CrossRef]

5. Streimikiene, D.; Balezentis, T.; Alisauskaite-Seskiene, I.; Stankuniene, G.; Simanaviciene, Z.; Seskiene, A. A Review of Willingness to Pay Studies for Climate Change Mitigation in the Energy Sector. Energies 2019, 12, 1481. [CrossRef]

6. Nemet, G.F.; Johnson, E. Willingness to Pay for Climate Policy: A Review of Estimates. SSRN Electron. J. 2010. [CrossRef]

7. Alló, M.; Loureiro, M.L. The role of social norms on preferences towards climate change policies: A meta-analysis. Energy Policy 2014, 73, 563-574. [CrossRef]

8. Ma, C.; Rogers, A.A.; Kragt, M.E.; Zhang, F.; Polyakov, M.; Gibson, F.; Chalak, M.; Pandit, R.; Tapsuwan, S. Consumers' willingness to pay for renewable energy: A meta-regression analysis. Resour. Energy Econ. 2015, 42, 93-109. [CrossRef]

9. Bigerna, S.; Polinori, P. Italian households' willingness to pay for green electricity. Renew. Sustain. Energy Rev. 2014, 34, 110-121. [CrossRef]

10. Fizaine, F.; Voye, P.; Baumont, C. Does the literature support a high willingness to pay for green label buildings? An answer with treatement of publication bias. Rev. D'Economie Polit. 2018, 128, 1013-1046.

11. Taylor, A.L.; Dessai, S.; de Bruin, W.B. Public perception of climate risk and adaptation in the UK: A review of the literature. Clim. Risk Manag. 2014, 4-5, 1-16. [CrossRef]

12. Oerlemans, L.A.; Chan, K.-Y.; Volschenk, J. Willingness to pay for green electricity: A review of the contingent valuation literature and its sources of error. Renew. Sustain. Energy Rev. 2016, 66, 875-885. [CrossRef]

13. D'Agostino, A.L.; Sovacool, B.K.; Bambawale, M.J. And then what happened? A retrospective appraisal of China's Renewable Energy Development Project (REDP). Renew. Energy 2011, 36, 3154-3165. [CrossRef] 
14. Guo, X.; Liu, H.; Mao, X.; Jin, J.; Chen, D.; Cheng, S. Willingness to pay for renewable electricity: A contingent valuation study in Beijing, China. Energy Policy 2014, 68, 340-347. [CrossRef]

15. Yang, J.; Zou, L.; Lin, T.; Wu, Y.; Wang, H. Public willingness to pay for $\mathrm{CO}_{2}$ mitigation and the determinants under climate change: A case study of Suzhou, China. J. Environ. Manag. 2014, 146, 1-8. [CrossRef] [PubMed]

16. Zhang, L.; $\mathrm{Wu}, \mathrm{Y}$. Market segmentation and willingness to pay for green electricity among urban residents in China: The case of Jiangsu Province. Energy Policy 2012, 51, 514-523. [CrossRef]

17. Zhu, L.; Song, Q.; Sheng, N.; Zhou, X. Exploring the determinants of consumers' WTB and WTP for electric motorcycles using CVM method in Macau. Energy Policy 2019, 127, 64-72. [CrossRef]

18. Bose, R.K.; Shukla, M. Electricity tariffs in India: An assessment of consumers' ability and willingness to pay in Guyarat. Energy Policy 2001, 29, 465-478. [CrossRef]

19. Ghosh, R.; Goyal, Y.; Rommel, J.; Sagebiel, J. Are small firms willing to pay for improved power supply? Evidence from a contingent valuation study in India. Energy Policy 2017, 109, 659-665. [CrossRef]

20. Graber, S.; Narayanan, T.; Alfaro, J.; Palit, D. Solar microgrids in rural India: Consumers' willingness to pay for attributes of electricity. Energy Sustain. Dev. 2018, 42, 32-43. [CrossRef]

21. Gunatilake, H.; Maddipati, N.; Patail, S. Willingness to Pay for Good Quality, Uninterrupted Power Supply in Rural Madhya Pradesh, India; South Asia Working Paper Series; Asian Development Bank (ADB): Manila, Philippines, 2012.

22. Kobayakawa, T.; Kandpal, T.C. Photovoltaic micro-grid in a remote village in India: Survey based identification of socio-economic and other characteristics affecting connectivity with micro-grid. Energy Sustain. Dev. 2014, 18, 28-35. [CrossRef]

23. Rahnama, R. Determinants of WTP among Energy-Poor Households: Implications for Planning Models and Frameworks; Oxford Institute for Energy Studies: Oxford, UK, 2019; ISBN 9781784671426.

24. Roy, J.; Jana, S. Solar lanterns for rural households. Energy 1998, 23, 67-68. [CrossRef]

25. Sagebiel, J.; Müller, J.R.; Rommel, J. Are consumers willing to pay more for electricity from cooperatives? Results from an online Choice Experiment in Germany. Energy Res. Soc. Sci. 2014, 2, 90-101. [CrossRef]

26. Gravitiani, E.; Antriyandari, E. Willingness to Pay for Climate Change Mitigation: Application on Big Cities in Central Java, Indonesia. Procedia Soc. Behav. Sci. 2016, 227, 417-423. [CrossRef]

27. Reinders, A. Perceived and Reported Reliability of the Electricity Supply at Three Urban Locations in Indonesia. Energies 2018, 11, 140. [CrossRef]

28. Schmidt, T.S.; Blum, N.U.; Wakeling, R.S. Attracting private investments into rural electrification-A case study on renewable energy based village grids in Indonesia. Energy Sustain. Dev. 2013, 17, 581-595. [CrossRef]

29. Afroz, R.; Hanaki, K.; Hasegawa-Kurisu, K.; Morshed, N.; Duasa, J.; Khalid, H. Willingness to pay of the households for solar energy-A case study in Kuala Lumpur. Int. Conf. Econ. Entrep. Manag. 2019, 90, 492-503.

30. Azlina, A.A.; Mahirah, K.; Sin, M.S. Willingness to pay for renewable energy: Evidence from Malaysian's Households. J. Ekon. Malays. 2018, 52, 153-161.

31. Wan Abdullah, W.M.Z.; Zainudin, W.N.R.A.; Mohamad Ishak, W.W. The scale validation of public participation of renewable energy (RE) development in Malaysia: An exploratory factor analysis (EFA). Int. J. Recent Technol. Eng. 2018, 7, 44-48.

32. Lin, C.-Y.; Syrgabayeva, D. Mechanism of environmental concern on intention to pay more for renewable energy: Application to a developing country. Asia Pac. Manag. Rev. 2016, 21, 125-134. [CrossRef]

33. Khamsay, P.; Takahashi, Y.; Nomura, H.; Yabe, M. Economic Valuation of River Conservation towards International Tourists' Preferences and Willingness to Pay for Ecofriendly Services of Hotel Industry: A Case Study of Namxong River in Vangvieng District, Laos. J. Water Resour. Prot. 2015, 7, 897-908. [CrossRef]

34. Khan, H.A.; Ahmad, H.F.; Nasir, M.; Nadeem, M.F.; Zaffar, N.A. Decentralised electric power delivery for rural electrification in Pakistan. Energy Policy 2018, 120, 312-323. [CrossRef]

35. Barrera, M.J.S. Powering Tourism: Wind Energy and Its Impact on Rural Tourism in Ilocos Norte, Philippines. Proc. Int. Conf. Econ. 2017, 2017, 129-155.

36. Suanmali, S.; Kokuenkan, K.; Lohananthachai, N.; Kumpong, N.; Suwatanapornchai, T. Factors affecting the willingness to pay for solar home systems: An empirical study in Bangkok, Nonthaburi, Pathum Thani, and Samut Prakan provinces, Thailand. ASEAN J. Manag. Innov. 2018, 5, 63-76.

37. Han, M.S.; Biying, Y.; Cudjoe, D.; Yuan, Q. Investigating willingness-to-pay to support solar energy research and development in Myanmar. Energy Policy 2020, 146, 111820. [CrossRef]

38. Alam, M.; Bhattacharyya, S. Are the off-grid customers ready to pay for electricity from the decentralized renewable hybrid mini-grids? A study of willingness to pay in rural Bangladesh. Energy 2017, 139, 433-446. [CrossRef]

39. Export.gov Burma-Energy. Available online: https:/ /www.export.gov/apex/article2?id=Burma-Energy (accessed on 21 July 2020).

40. ADB Myanmar: Energy Sector Assessment. Strategy, and Road Map; Asian Development Bank: Manila, Philippines, 2016.

41. Du Pont, P. Decentralizing power: The Role of State and Region Governments in Myanmar's Energy Sector; The Asia Foundation: Yangon, Myanmar, 2019.

42. Alvarez, D.D.B.; Sugiyama, M. A SWOT Analysis of Utility-Scale Solar in Myanmar. Energies 2020, 13, 884. [CrossRef] 
43. IEA Countries: Myanmar. Available online: https://www.iea.org/countries/Myanmar (accessed on 4 February 2020).

44. International Finance Corporation Strategic Environmental Assessment of the Myanmar Hydropower Sector Final Report; International Finance Corporation: Washington, DC, USA, 2018.

45. Burke, A.; Williams, N.; Barron, P.; Jolliffe, K.; Carr, T. The Contested Areas of Myanmar: Subnational Conflict, Aid, and Development; Asia Foundation: Yangon, Myanmar, 2017.

46. Nam, K.; Cham, M.R.; Halili, P.R. Power Sector Development in Myanmar; ADB economics working paper series; Asian Development Bank: Manila, Philippines, 2015.

47. Tun, M.M.; Juchelková, D. Tun Biomass Sources and Energy Potential for Energy Sector in Myanmar: An Outlook. Resources 2019, 8, 102. [CrossRef]

48. JICA; NEWJEC Inc. The Kansai Electric Power Data Collection Survey on Capacity Development of Power Sector Development Planning in the Republic of the Union of Myanmar; JICA: Tokyo, Japan, 2015.

49. Pyithu Hluttaw. The 12th Regular Session of the 2nd Pyithu Hluttaw. 27 May 2019. Available online: https:/ / www.youtube. $\mathrm{com} /$ watch?v=WQ0K10G_Tas\&feature=youtu.be (accessed on 24 January 2020). (In Burmese)

50. UNFCCC. UNFCCC Sites and platforms Myanmar. Available online: https://unfccc.int/node/61122 (accessed on 20 July 2020 ).

51. UNFCCC. The Republic of the Union of Myanmar Myanmar's Intended Nationally Determined Contribution-INDC; UNFCCC: Bonn, Germany, 2015.

52. Central Statistical Organization Myanmar; UNDP; World Bank. Myanmar Living Conditions Survey 201703 Poverty Report; Central Statistical Organization Myanmar; UNDP; World Bank: Nay Pyi Taw, Myanmar, 2019.

53. Thant, H. Govt Claims Half of Myanmar Households Will Have Power by Year-End. Available online: https://www.mmtimes. $\mathrm{com} /$ news/govt-claims-half-myanmar-households-will-have-power-year-end.html (accessed on 30 April 2020).

54. Train, K.E. Discrete Choice Methods with Simulation; Cambridge University Press: Cambridge, UK, 2003; pp. 1-388.

55. McFadden, D.L. Conditional Logit Analysis of Qualitative Choice Behavior. In Frontiers in Econometrics; Zarembka, P., Ed.; Academic Press: New York, NY, USA, 1973; pp. 105-142.

56. Rodríguez, G. Lecture Notes on Generalized Linear Models. Available online: https://data.princeton.edu/wws509/notes/ (accessed on 12 January 2021).

57. Kuriyama, K.; Ishii, Y. Environmental Value of Recycled Goods and Market Share: Conjoint Analysis Study; Forest Economics and Policy Working Paper; Department of Forest Science, Faculty of Agriculture, Hokkaido University: Sapporo, Japan, 1998.

58. Hess, S.; Palma, D. Apollo: A Flexible, Powerful and Customisable Freeware Package for Choice Model Estimation and Application Version 0.1.0 User Manual. Available online: http:/ / www.apollochoicemodelling.com/files / Apollo.pdf (accessed on 7 January 2021)

59. Ko, T.K. Renewable Energy Law in the Works to Speed Up Development. Available online: https://www.mmtimes.com/news/ renewable-energy-law-works-speed-development.html (accessed on 6 February 2020).

60. De Bekker-Grob, E.W.; Donkers, B.; Jonker, M.F.; Stolk, E.A. Sample Size Requirements for Discrete-Choice Experiments in Healthcare: A Practical Guide. Patient Patient Cent. Outcomes Res. 2015, 8, 373-384. [CrossRef]

61. Department of Population Ministry of Labour Immigration and Population. The 2014 Myanmar Population and Housing Census Mandalay Region, Mandalay District Chanmyatharzi Township Report. Available online: https://themimu.info/sites/themimu. info/files/documents/TspProfiles_Census_Chanmyatharzi_2014_ENG.pdf (accessed on 27 January 2021).

62. World Bank Myanmar-Official Exchange Rate, LCU per USD, Period Average. Available online: https://tradingeconomics.com/ myanmar / official-exchange-rate-lcu-per-usd-period-average-wb-data.html\#: \{\}:text=Officialexchangerate\%2CLCUperUSD\% 2CperiodaverageinMyanmar,compiledfromofficiallyrecognizedsources (accessed on 20 January 2021).

63. Borchers, A.M.; Duke, J.M.; Parsons, G.R. Does willingness to pay for green energy differ by source? Energy Policy 2007, 35, 3327-3334. [CrossRef]

64. Longo, A.; Markandya, A.; Petrucci, M. The internalization of externalities in the production of electricity: Willingness to pay for the attributes of a policy for renewable energy. Ecol. Econ. 2008, 67, 140-152. [CrossRef]

65. Li, H.; Berrens, R.P.; Bohara, A.K.; Jenkins-Smith, H.C.; Silva, C.L.; Weimer, D.L. Would developing country commitments affect US households' support for a modified Kyoto Protocol? Ecol. Econ. 2004, 48, 329-343. [CrossRef]

66. Bergmann, A.; Hanley, N.; Wright, R. Valuing the attributes of renewable energy investments. Energy Policy 2006, 34, 1004-1014. [CrossRef]

67. Berrens, R.P.; Bohara, A.K.; Jenkins-Smith, H.C.; Silva, C.L.; Weimer, D.L. Information and effort in contingent valuation surveys: Application to global climate change using national internet samples. J. Environ. Econ. Manag. 2004, 47, 331-363. [CrossRef]

68. Lee, C.-Y.; Heo, H. Estimating willingness to pay for renewable energy in South Korea using the contingent valuation method. Energy Policy 2016, 94, 150-156. [CrossRef]

69. Myanmar Energy Monitor; Frontier Myanmar Research Ltd.: Yangon, Myanmar, 2020.

70. JICA Data Collection Survey on Capacity Development of Power Sector Development Planning in the Republic of the Union of Myanmar: Final Report Summary; JICA: Tokyo, Japan, 2015.

71. Vaghela, D. Myanmar's Renewable Energy Minigrids: Technology Differentiation. In Proceedings of the ADB Myanmar Off-Grid Investment Forum; Asian Development Bank: Nay Pyi Taw, Myanmar, 2017; p. 11. 
72. Numata, M.; Sugiyama, M.; Mogi, G. Barrier Analysis for the Deployment of Renewable-Based Mini-Grids in Myanmar Using the Analytic Hierarchy Process (AHP). Energies 2020, 13, 1400. [CrossRef]

73. Central Statistical Organization; UNDP; World Bank. Myanmar Living Conditions Survey 2017: Key Indicators Report; Central Statistical Organization Myanmar; UNDP: Nay Pyi Taw, Myanmar; World Bank: Yangon, Myanmar, 2018. 